\title{
The desire to hasten death in advanced cancer patients at a Mexican palliative care service
}

\author{
Oscar Rodríguez-Mayoral,' Leticia Ascencio-Huertas, ' Emma Verástegui,,' Marvin O. Delgado-Guay, ${ }^{2}$ Silvia \\ Allende-Pérez
}

Servicio de Cuidados Paliativos, Instituto Nacional de Cancerología, Ciudad de México, México.

2 Department of Palliative, Rehabilitation and Integrative Medicine, The University of Texas, MD Anderson Cancer Center, Houston, Texas.

\section{Correspondence:}

Oscar Rodríguez-Mayoral Servicio de Cuidados Paliativos, Instituto Nacional de Cancerología. Av. San Fernando 22, Col. Sección XVI. Alcaldía Tlalpan, C. P. 14080, Ciudad de México, México.

Phone: + 52555628 - 0400, ext. 44025

E-mail: orodriguezm@incan.edu.mx

Received: 5 December 2018

Accepted: 26 June 2019

\section{Citation:}

Rodríguez-Mayoral, O., Ascencio-Huertas, L., Verástegui, E., Delgado-Guay, M. Ó., \& Allende-Pérez, S. (2019). The desire to hasten death in advanced cancer patients at a Mexican Palliative Care Service. Salud Mental, 42(3), 103-109.

DOI: $10.17711 /$ SM.0185-3325.2019.014

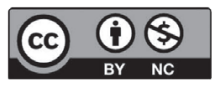

\begin{abstract}
Introduction. The desire to hasten death (DHD) might be present in patients with advanced cancer. Multiple distressing physical and psychosocial symptoms may be related to it. There is limited literature about the characteristics of these patients in México. Objective. To describe the prevalence and factors associated with DHD in advanced cancer patients evaluated by a palliative care psychiatrist. Method. We conducted a cross-sectional study, including all patients referred to psychiatric assessment at the Servicio de Cuidados Paliativos of the Instituto Nacional de Cancerología in Mexico City, from January to December 2016. DHD was defined as the presence of death ideas, suicidal ideation, and/or request for euthanasia or medically assisted suicide. Patients with delirium, dementia, psychosis, or uncontrolled physical symptoms were excluded. Results. Sixty-four patients were included in the study. Most of them were women (59\%); the mean age was 49 years old $(S D=16)$. Of them, $64 \%$ met criteria for a major depressive disorder, $64 \%$ for generalized anxiety disorder and/or panic disorder, and $11 \%$ for substance use disorders. $44 \%$ expressed DHD. In a multivariate regression analysis predicting DHD, only one factor emerged: clinical depression $(O R=13.5, p=.002,95 \%$ $\mathrm{Cl}[02.562,71.726])$. Discussion and conclusion. The desire to hasten death is a frequent issue for the patients evaluated at the psychiatric palliative care clinic. Depression and other distressing psychiatric pathologies were associated with DHD. Interdisciplinary interventions are needed to treat DHD. More research is warranted in order to understand the factors associated with the expression of DHD.
\end{abstract}

Keywords: Desire to hasten death, advanced cancer, palliative care, depression.

\section{RESUMEN}

Introducción. El deseo de acelerar la muerte (DHD, por sus siglas en inglés) es frecuente en pacientes con cáncer avanzado. Múltiples estresores físicos y psicosociales se asocian a la presencia de este fenómeno. En México es limitada la información sobre estos pacientes. Objetivo. Describir la prevalencia y los factores asociados con la presencia del DHD en pacientes con cáncer avanzado evaluados por el psiquiatra de cuidados paliativos. Método. Realizamos un estudio transversal, incluimos a todos los pacientes referidos a evaluación psiquiátrica en el Servicio de Cuidados Paliativos del Instituto Nacional de Cancerología en la Ciudad de México, de enero a diciembre de 2016. EI DHD se definió como la presencia de ideas de muerte, ideación suicida y/o solicitud de eutanasia o suicidio médicamente asistido. Se excluyeron los pacientes con delirium, demencia, psicosis o algún síntoma físico descontrolado. Resultados. Sesenta y cuatro pacientes fueron incluidos en el estudio; $59 \%$ fueron mujeres; la edad media era de 49 años $(D E=16)$. El $64 \%$ cumplieron criterios para un trastorno depresivo mayor, el $64 \%$ para el trastorno de ansiedad generalizada y/o trastorno de pánico y el $11 \%$ para los trastornos por uso de sustancias; $44 \%$ expresaron DHD. En un análisis de regresión multivariable, el factor depresión mayor $(O R=13.5 ; p=.002$, IC 95\% [02.562, 71.726]) fue el único significativo. Discusión y conclusión. El DHD es frecuente en los pacientes valorados por psiquiatría de cuidados paliativos. La depresión mayor se asoció con DHD. Se necesitan intervenciones interdisciplinarias para tratar el DHD. Se requiere más investigación para comprender los factores asociados con la expresión de DHD.

Palabras clave: Deseos de adelantar la muerte, cáncer avanzado, cuidados paliativos, depresión. 


\section{INTRODUCTION}

Cancer is a leading cause of mortality worldwide and represents a growing threat in Latin American countries, where most cancer cases are diagnosed in advanced stages. This not only reduces chances of cure, but also increases treatment costs and generates a great need for palliative care to relieve pain and suffering, thus improving the quality of life of patients who face life-threatening illnesses (Strasser-Weippl, Chavarri-Guerra, Villarreal-Garza, Bychkovsky, et al., 2015).

Patients with advanced cancer can experience physical, psychological, social, and spiritual distress as a consequence of their illness and treatments (Allende-Pérez \& Verástegui-Avilés, 2013) that affect their overall quality of life (Polanski, Jankowska-Polanska, Rosinczuk, Chabowski, \& Szymanska-Chabowska, 2016). This population often has multiple forms of suffering and is prone to express ideas of death and suicide (Ballard, Pao, Henderson, Lee et al., 2008; Zhong, Li, Lv, Tian, Liu, et al., 2017), requesting euthanasia or assisted suicide. These type of ideas are synthesized within the term "desire to hasten death" (DHD) (Breitbart, Rosenfeld, Pessin, Kaim, Funesti-Esch et al., 2000).

The DHD in terminal patients is a subject that has a growing interest in medical literature due to its importance on policies and decisions at the end of life (Chao, Boivin, Marcoux, Garnon, Mays et al., 2016). It has been described as a consequence of the suffering generated by life-threatening diseases and for which patients find no other solution than to accelerate their own death. It is a response to factors such as uncontrolled physical symptoms, psychological distress, social or existential suffering, and/or the presence of psychiatric disorders. The DHD must be set apart from the acceptance of imminent death or the desire to die naturally in the near future (Balaguer, Monforte-Royo, Porta-Sales, Alonso-Babarro, Altisent et al., 2016; Wilson, Dalgleish, Chochinov, Chary, Gagnon et al., 2016).

There are different psychometric instruments designed to evaluate and diagnose DHD (Chochinov, Wilson, Enns, Mowchun, Lander et al., 1995; Kelly, Burnett, Pelusi, Badger, Varghese et al., 2003; Rosenfeld, Breitbart, Galietta, Kaim, Funesti-Esch et al., 2000) in vulnerable populations. These instruments quantify the presence of DHD which enables comparisons between populations. Currently, we do not have the validation of these instruments to measure DHD in Mexican population (Bellido-Pérez, Monforte-Royo, Tomás-Sábado, Porta-Sales, \& Balaguer, 2017).

The presence of DHD is common in patients who face advanced or life-threatening illnesses such as cancer. Incidence levels are variable due to the different populations and diagnostic tools used in the studies (Kremeike, Galushko, Frerich, Romotzky, Hamacher et al., 2018; Zhong et al., 2017). In patients treated in palliative care units, $11 \%$ to $55 \%$ of the patients experience momentary DHD and
$3 \%$ to $20 \%$ experience a permanent DHD (Wilson et al., 2016). On the other hand, $35 \%$ of the patients who undergo psychiatric assessment are found to have DHD (Madeira, Albuquerque, Santos, Mendes, \& Roque, 2011).

Different factors associated with the presence of DHD have been described, including: being a woman, oncological diagnosis (pancreas, liver, lung, head, and neck), presence of uncontrolled physical symptoms (such as pain, nausea, fatigue) (Breitbart et al., 2000; Julião, Barbosa, Oliveira, \& Nunes, 2013), decrease in functionality, impact on physical appearance (Kumar, Chaudhary, Soni, \& Jha, 2017; Zhong et al., 2017), unstable interpersonal relationships, poor support networks, fear of physical and psychological suffering (Quill, Back, \& Block, 2016), loss of autonomy and dignity, feeling they are a burden for others (Chochinov, 2016), and the presence of psychiatric disorders such as depression and anxiety (Julião et al., 2013; Madeira et al., 2011; Mehta \& Roth, 2015; Wilson et al., 2016). The latter can also have a negative impact on therapeutic adherence, hospital admissions, quality of life, and survival (Arrieta, Angulo, Núñez-Valencia, Dorantes-Gallareta, Macedo et al., 2013).

The desire to hasten death has been identified more frequently in patients with terminal illnesses; however, in its essence, it is an expression of suffering, and not necessarily a genuine desire to die (Wilson, Chochinov, Skirko, Allard, Chary et al., 2007). Therefore, it is necessary to identify the physical, psychological, social, and spiritual factors or needs that generate suffering in order to provide an adequate control of the symptoms through holistic attention (Wilson et al., 2016). When patients don't have access to this type of attention, controlling their physical, emotional, and spiritual symptoms becomes more difficult and the end of life journey tends to be more painful (Wilson et al., 2007; 2016).

Faced with this imminent need and due to the limited studies on DHD in Latin America, the purpose of this study was to establish its prevalence and the demographic factors and psychiatric disorders associated with the desire to hasten death in patients with advanced cancer evaluated by a psychiatrist at the Servicio de Cuidados Paliativos (SCP) of the Instituto Nacional de Cancerología (INCan) in Mexico City.

\section{METHOD}

\section{Participants and measures}

An observational, cross-sectional study, with non-probabilistic and consecutive sampling was performed. The study was approved by the local Research Committee.

All patients referred to an initial psychiatric palliative assessment (by the medical/psychologist palliative care specialist criteria) from January to December of 2016 at the (SCP) of the INCan in Mexico City were screened for inclusion. Patients with uncontrolled physical symptoms 
(pain, nausea, dyspnea, etc.), cognitive disorders (delirium, dementia), psychosis, neurological deterioration associated to the presence of brain metastases (corroborated by MRI), serious communication problems, and patients receiving antidepressant pharmacological treatment in antidepressant doses (Armstrong, 2011) at the time of psychiatric assessment were excluded. For this study, the following variables were collected: sociodemographic characteristics, clinical oncologic information, functionality through Karnofsky Index (Yates, Chalmer, \& McKegney, 1980) and the Eastern Cooperative Oncology Group (ECOG) scale (Oken, Creech, Tormey, Horton, Davis et al., 1982), opioid treatment (morphine equivalent dose, MED) (Mercadante \& Bruera, 2016), use of psychotropic drugs, symptom evaluation through the Edmonton Symptom Assessment System (ESAS) (Bruera, Kuehn, Miller, Selmser, \& Macmillan, 1991) as a categorical variable $(<5$ and $\geq 5$ ), clinical prediction of survival by the Palliative Prognosis Index (PPI) (Morita, Tsunoda, Inoue, \& Chihara, 1999), and if palliative care was given with (Group A) or without (Group B) simultaneous disease-modifying treatment.

All patients included were evaluated following the standard procedures of Psychiatric Palliative Care Clinic. Diagnoses were made according to the criteria of the Diagnostic and Statistical Manual of Mental Disorders $5^{\text {th }}$ edition (American Psychiatric Association, 2014). The desire to hasten death was defined as the presence of ideas of death and/or suicidal ideation and/or request for euthanasia and/or medically assisted suicide request.

\section{Statistical analysis}

Patient characteristics and symptom assessments were summarized using descriptive statistics including means, frequencies, and percentages. A univariate logistic regression was performed between the characteristic of interest (DHD) and each variable to explore the possible associations. From these results, we selected the variables with statistical significance $(p<.05)$ for the multivariate analysis. The logistic regression model was then built using forward selection. All analyses were performed using STATA version 12.1 software (StataCorp. 2011).

\section{RESULTS}

\section{Sample characteristics}

We included 64 patients in the study, of which 37/64 (57.8\%) were women with a mean age of 49 years $(S D=15.7)$. A slightly higher percentage of patients were single (42\%) and $39 \%$ were married. Most patients had six or less years of formal education (28\%). The sociodemographic characteristics of the patients included are shown in Table 1.

Table 1

Demographic characteristics $(N=64)$

\begin{tabular}{|c|c|c|c|c|c|c|c|}
\hline & \multicolumn{2}{|c|}{ With $D H D(n=28)$} & \multicolumn{2}{|c|}{ Without DHD $(n=36)$} & \multirow[b]{2}{*}{ OR } & \multirow[b]{2}{*}{$p$ Value ${ }^{a}$} & \multirow[b]{2}{*}{$95 \% \mathrm{Cl}$} \\
\hline & $\begin{array}{c}\text { Mean } \\
n\end{array}$ & $\begin{array}{c}S D \\
\%\end{array}$ & $\begin{array}{c}\text { Mean } \\
n\end{array}$ & $\begin{array}{c}S D \\
\%\end{array}$ & & & \\
\hline$\overline{\text { Age }}$ & 49.96 & 10.85 & 47.75 & 18.72 & 1 & .573 & $.977-1.041$ \\
\hline \multicolumn{8}{|l|}{ Sex } \\
\hline Female & 20 & 31.3 & 17 & 26.6 & Ref & & \\
\hline Male & 8 & 12.5 & 19 & 29.7 & 2.79 & .05 & $.978-07.976$ \\
\hline \multicolumn{8}{|l|}{ Marital status } \\
\hline Single & 10 & 15.6 & 17 & 26.6 & Ref & & \\
\hline Married/cohabiting & 14 & 21.9 & 11 & 17.2 & 2.16 & .17 & $.712-06.570$ \\
\hline Widowed & 1 & 1.6 & 6 & 9.4 & .28 & .27 & $.029-02.705$ \\
\hline Divorced & 3 & 4.7 & 2 & 3.1 & 2.55 & .35 & $.361-17.963$ \\
\hline \multicolumn{8}{|l|}{ Education } \\
\hline None & 0 & 0 & 2 & 3.1 & - & & \\
\hline Elementary school & 10 & 15.6 & 8 & 12.5 & Ref & & \\
\hline Junior high school & 0 & 0 & 2 & 3.1 & .36 & .16 & $.088-01.486$ \\
\hline High school & 6 & 9.4 & 7 & 10.9 & .69 & .61 & $.163-02.873$ \\
\hline College & 7 & 10.9 & 6 & 9.4 & .93 & .93 & $.222-03.911$ \\
\hline Comunity college & 0 & 0 & 2 & 3.1 & - & & \\
\hline \multicolumn{8}{|l|}{ Religion } \\
\hline With religion & 26 & 40.6 & 33 & 51.6 & Ref & & \\
\hline Without religion & 2 & 3.1 & 3 & 4.7 & .85 & .86 & $.131-05.440$ \\
\hline
\end{tabular}

Notes: DHD: Desire to hasten death; a Calculated using logistic regression. 
Table 2

Clinical characteristics $(N=64)$

\begin{tabular}{|c|c|c|c|c|c|c|c|}
\hline & \multicolumn{2}{|c|}{ With $D H D(n=28)$} & \multicolumn{2}{|c|}{ Without DHD $(n=36)$} & \multirow[b]{2}{*}{ OR } & \multirow[b]{2}{*}{$p$ Value $^{a}$} & \multirow[b]{2}{*}{$95 \% \mathrm{Cl}$} \\
\hline & $\begin{array}{c}\text { Mean } \\
n\end{array}$ & $\begin{array}{c}S D \\
\%\end{array}$ & $\begin{array}{c}\text { Mean } \\
n\end{array}$ & $\begin{array}{c}S D \\
\% \\
\end{array}$ & & & \\
\hline Morphine (mg/day) & 64.6 & 47.5 & 79.8 & 68.3 & .99 & .468 & $.988-1.005$ \\
\hline \multicolumn{8}{|l|}{ Site of tumors } \\
\hline Gastrointestinal & 5 & 7.8 & 4 & 6.3 & Ref & & \\
\hline Hematology & 0 & 0 & 4 & 6.3 & - & & \\
\hline Liver and bile duct & 3 & 4.7 & 2 & 3.1 & 1.2 & .87 & $.130-11.050$ \\
\hline Lung & 3 & 4.7 & 2 & 3.1 & 1.2 & .87 & $.130-11.050$ \\
\hline Skin and soft tissue & 2 & 3.1 & 5 & 7.8 & .32 & .29 & $.039-02.617$ \\
\hline Gynecological & 5 & 7.8 & 3 & 4.7 & 1.3 & .77 & $.190-09.311$ \\
\hline Urology & 4 & 6.3 & 5 & 7.8 & .64 & .68 & $.009-04.108$ \\
\hline Breast & 4 & 6.3 & 5 & 7.8 & .64 & .68 & $.009-04.108$ \\
\hline Head and neck & 0 & 0 & 4 & 6.3 & - & & \\
\hline Melanoma & 1 & 1.6 & 2 & 3.1 & .4 & .51 & $.025-06.175$ \\
\hline Unknown & 1 & 1.6 & 0 & 0 & - & & \\
\hline \multicolumn{8}{|l|}{ Karnovsky } \\
\hline 40 & 1 & 1.6 & 2 & 3.1 & Ref & & \\
\hline 50 & 4 & 6.3 & 5 & 7.8 & 1.6 & .74 & $.103-24.703$ \\
\hline 60 & 4 & 6.3 & 6 & 9.4 & 1.3 & .84 & $.088-20.108$ \\
\hline 70 & 12 & 18.8 & 10 & 15.6 & 2.4 & .5 & $.188-30.520$ \\
\hline 80 & 4 & 6.3 & 10 & 15.6 & .8 & .87 & $.056-11.504$ \\
\hline 90 & 3 & 4.7 & 3 & 4.7 & 2 & .64 & $.111-35.806$ \\
\hline \multicolumn{8}{|l|}{ ESAS } \\
\hline Pain $<5$ & 20 & 31.3 & 29 & 45.3 & Ref & & \\
\hline Pain $\geq 5$ & 8 & 12.5 & 7 & 10.9 & 1.5 & .47 & $.469-05.095$ \\
\hline Tiredness $<5$ & 17 & 26.6 & 24 & 37.5 & Ref & & \\
\hline Tiredness $\geq 5$ & 11 & 17.2 & 12 & 18.8 & 1.2 & .68 & $.442-03.476$ \\
\hline Nausea $<5$ & 22 & 34.4 & 31 & 48.4 & Ref & & \\
\hline Nausea $\geq 5$ & 6 & 9.4 & 5 & 7.8 & 1.7 & .44 & $.443-06.467$ \\
\hline Drowsiness $<5$ & 23 & 35.9 & 24 & 37.5 & Ref & & \\
\hline Drowsiness $\geq 5$ & 5 & 7.8 & 12 & 18.8 & .3 & .08 & $.097-01.143$ \\
\hline Appetite $<5$ & 21 & 32.8 & 26 & 40.6 & Ref & & \\
\hline Appetite $\geq 5$ & 7 & 10.9 & 10 & 15.6 & .7 & .68 & $.243-02.512$ \\
\hline Well-being $<5$ & 15 & 23.4 & 21 & 32.8 & Ref & & \\
\hline Well-being $\geq 5$ & 13 & 20.3 & 15 & 23.4 & 1.06 & .92 & $.334-03.352$ \\
\hline Shortness of breath $<5$ & 23 & 35.9 & 35 & 54.7 & Ref & & \\
\hline Shortness of breath $\geq 5$ & 5 & 7.8 & 1 & 1.6 & 6.7 & .09 & $.730-62.360$ \\
\hline Insomnia < 5 & 22 & 34.4 & 28 & 43.8 & Ref & & \\
\hline Insomnia $\geq 5$ & 6 & 9.4 & 8 & 12.5 & 0.8 & .71 & $.230-02.702$ \\
\hline Constipation $<5$ & 22 & 34.4 & 29 & 45.3 & Ref & & \\
\hline Constipation $\geq 5$ & 6 & 9.4 & 7 & 10.9 & 0.9 & .93 & $.270-03.322$ \\
\hline \multicolumn{8}{|l|}{ ECOG } \\
\hline 1 & 8 & 12.5 & 11 & 17.2 & Ref & & \\
\hline 2 & 15 & 23.4 & 19 & 29.7 & 1.09 & .89 & $.348-03.376$ \\
\hline 3 & 5 & 7.8 & 6 & 9.4 & 1.1 & .86 & $.256-05.114$ \\
\hline \multicolumn{8}{|l|}{ PPI } \\
\hline$A$ & 13 & 20.3 & 18 & 28.1 & Ref & & \\
\hline $\mathrm{B}$ & 10 & 15.6 & 13 & 20.3 & 1 & .91 & $.358-03.168$ \\
\hline $\mathrm{C}$ & 5 & 7.8 & 5 & 7.8 & 1.4 & .66 & $.331-05.787$ \\
\hline \multicolumn{8}{|l|}{ Medical follow-up } \\
\hline Palliative care patients & 14 & 21.9 & 23 & 35.9 & Ref & & \\
\hline Hospice patients & 14 & 21.9 & 13 & 20.3 & 1.76 & .27 & $.647-04.830$ \\
\hline
\end{tabular}

Notes: DHD: Desire to hasten death; PPI: Palliative Prognosis Index; ESAS: Edmonton Symptom Assessment System; a Calculated using logistic regression. 
Table 3

Psychiatric disorder

\begin{tabular}{|c|c|c|c|c|c|c|c|}
\hline & \multicolumn{2}{|c|}{ With $D H D$} & \multicolumn{2}{|c|}{ Without DHD } & \multirow[b]{2}{*}{ OR } & \multirow[b]{2}{*}{$p$ Value } & \multirow[b]{2}{*}{$95 \% \mathrm{Cl}$} \\
\hline & $n$ & $\%$ & $n$ & $\%$ & & & \\
\hline \multicolumn{8}{|c|}{ Major depressive disorder } \\
\hline Yes & 26 & 40.6 & 15 & 23.4 & & & \\
\hline No & 2 & 3.1 & 21 & 32.8 & 18.20 & .000 & $03.735-88.670$ \\
\hline \multicolumn{8}{|c|}{ Anxiety disorder } \\
\hline Yes & 22 & 34.4 & 19 & 29.7 & & & \\
\hline No & 6 & 9.4 & 17 & 26.6 & 3.28 & .037 & $01.075-10.000$ \\
\hline \multicolumn{8}{|c|}{ Substance use disorders } \\
\hline Yes & 3 & 4.7 & 4 & 6.3 & & & \\
\hline No & 25 & 39.1 & 32 & 50.0 & 1.10 & .892 & $.130-11.150$ \\
\hline
\end{tabular}

Notes: DHD: Desire to hasten death; a Calculated using logistic regression.

The most frequent sites of cancer were: gynecological $(17 \%)$, breast $(12 \%)$, and urological (14\%). Karnofsky Index score was 70 in $34 \%$ of the patients, and ECOG 2 in $53 \%$ of patients. A high percentage of patients $(81.3 \%)$ were receiving strong opioids treatment (MED) with a median dose of $73.1 \mathrm{mg} /$ day $(S D=60)$ (range 15 - 270), 6/64 received treatment with amitriptyline as pain treatment (mean $27.1 \mathrm{mg} /$ day, $S D=12.3$ ). Clinical characteristics are shown in Table 2. Of the patients included in the study, the most frequent reasons for referral to psychiatric evaluation were: depression (51.8\%), adjustment disorder (14.3\%), anxiety $(12.5 \%)$, history of substance abuse (7.1\%), and explicit desire or ideas of death/euthanasia/assisted suicide $(5.4 \%)$.

The criteria for major depressive disorder were met in $41 / 64(64 \%)$. The same percentage (64\%) met the criteria for generalized anxiety disorder and/or panic disorder, and 7/64 (11\%) had substance use disorders (Table 3).

\section{Prevalence of desire to hasten death}

During the psychiatric evaluation, $44 \%$ of the patients expressed some form of desire to hasten death $(42 \%$ had ideas of death, 14\% had suicidal ideation, 9\% conveyed a request for euthanasia or medically assisted suicide) (Table 4).

\section{Desire to hasten death: associated factors}

Patients who presented DHD were mostly women (20 women / 8 men versus 17 women / 19 men, $p=.05$ ), or met criteria for major depressive disorder (40.6\% versus $23.4 \%, p=.000$ ) or an anxiety disorder (34.4\% versus $29.7 \%, p=.037)$, in comparison to those who did not express a DHD (Table 4).

The univariate analysis (Tables 1, 2, and 3) showed a significant association between DHD and women $(O R=2.794$, $p=.05,95 \%$ CI $[0.978,7.98])$, presence of major depressive disorder $(O R=18.20, p<.000,95 \%$ CI [3.76, 88.67]), or any anxiety disorder $(O R=3.28, p=.037,95 \% \mathrm{CI}[1.075,10])$.

In the multivariate analysis, the variables included were: sex, presence of major depressive disorder, and presence of any anxiety disorder. Only the major depressive disorder continued to be significant $(O R=13.5, p=.002,95 \% \mathrm{CI}$ $[2.562,71.726])$ (Table 5).

\section{DISCUSSION AND CONCLUSION}

This is the first study describing the characteristics of Mexican palliative cancer patients who present a desire to hasten death. In our study we found a high prevalence, with $44 \%$ of patients referred for psychiatric evaluation expressing a DHD. This prevalence is higher in comparison to what other authors have described (Madeira et al., 2011). This may be due to the use of the professional clinical interview to evaluate DHD, as it may provide a more sensitive and specific method of diagnosis of DHD.

Also, 64\% of the patients who expressed a DHD, met the criteria for major depressive disorder, as previously reported (Chochinov et al., 1995; Julião et al., 2013; Wilson

Table 4

Desire to hasten death classification

\begin{tabular}{|c|c|c|c|c|c|c|c|c|}
\hline & \multicolumn{2}{|c|}{ Death ideas } & \multicolumn{2}{|c|}{ Suicidal ideas } & \multicolumn{2}{|c|}{$\begin{array}{c}\text { Euthanasia } \\
\text { request/Medical } \\
\text { assisted suicide }\end{array}$} & \multicolumn{2}{|c|}{$\begin{array}{c}\text { Wish to hasten } \\
\text { death }\end{array}$} \\
\hline & $\mathrm{N}$ & $\%$ & $\mathrm{~N}$ & $\%$ & $\mathrm{~N}$ & $\%$ & $\mathrm{~N}$ & $\%$ \\
\hline Yes & 27 & 42.2 & 9 & 14.1 & 6 & 9.4 & 28 & 43.8 \\
\hline No & 37 & 57.8 & 55 & 85.9 & 58 & 90.6 & 36 & 56.3 \\
\hline
\end{tabular}


Table 5

Multivariate analysis

\begin{tabular}{lrcr}
\hline Variables & OR & $p$ Value & \multicolumn{1}{c}{ Cl } \\
\hline Sex & 1.4 & .566 & $.409-05.130$ \\
Major depressive disorder & 13.5 & .002 & $02.562-71.726$ \\
Anxiety disorder & 1.9 & .330 & $.519-07.022$ \\
\hline
\end{tabular}

Note: a Calculated using logistic regression.

et al., 2016). A high percentage of patients (64\%) also met criteria for any anxiety disorder, which agrees with what has been reported by Madeira et al., (2011) and Wilson et al., (2016). The analysis shows that major depressive disorder increases 14 times the risk to express DHD, which is consistent with previous findings (Breitbart et al., 2000; Julião et al., 2013; Wilson et al., 2016). Very often psychiatric disorders are underdiagnosed and undertreated in general medical practice, which makes it extremely important to adopt proper measures to identify and provide a prompt integral attention (Wilson et al., 2016).

Results show that female patients have a higher prevalence of DHD, but it is not clear if this association could be explained due to the high prevalence of depression in this population, a factor that could trigger the request to hasten death (Wagner, González-Forteza, Sánchez-García, GarcíaPeña, \& Gallo, 2012). More research is warranted to better understand this relationship.

No association was found between the presence of physical symptoms (measured by ESAS) and the expression of DHD. However, a tendency similar to other studies was observed in the association between DHD and shortness of breath and drowsiness (Julião et al., 2013; Wilson et al., 2016). Our results suggest that psychiatric disorders and/or uncontrolled physical symptoms should be assessed and treated in patients with presence of DHD.

No association was found between DHD and formal school education years, marital status, religion, oncological diagnosis, performance status (Karnofsky and ECOG), morphine dose (MED), PPI, substance use disorders, or receiving or not active oncological treatment.

An interesting finding in our study are the reasons for requesting a psychiatric evaluation. Most cases of DHD were detected during the palliative-psychiatric interview (75\%). During routine palliative care evaluation, only $8 \%$ of the patients expressed a DHD to the palliative care physician (main reason for psychiatric referral was depression). This suggests that the presence of DHD is rarely explored even in palliative care, possibly because of the myths and stigma surrounding this topic. Families and loved ones may think that having conversations about death with patients with an advanced incurable chronic disease may contribute to the patient's despair and thoughts about hastening death (Kremeike et al., 2018; Saxena, Krug, Chestnov, \& World Health Organization, 2014).
Nevertheless, it is necessary to intentionally explore DHD. The presence of these type of thoughts might not be a genuine desire to die (Wilson et al., 2007), but an expression of suffering, and often of some other psychiatric disorder (mainly depression). Bringing up the topic may help relieve the tension. It's important to identify the possible causes of DHD in order to decide the best possible treatment to improve the patient's and their family's quality of life (Kremeike et al., 2018; Saxena et al., 2014). Further research is required.

This study has several limitations: it is a cross-sectional study, the sample size is relatively small, and there is bias in the population studied due to the selection of patients who were only referred to psychiatric assessment. This means the findings are not conclusive for the entire palliative cancer care population, but are a good description of a particular population. Also, other relevant factors were not evaluated, such as dignity (Houmann, Chochinov, Kristjanson, Petersen, \& Groenvold, 2014), demoralization (Vehling, Kissane, Lo, Glaesmer, Hartung et al., 2017), and spirituality (Delgado-Guay, Hui, Parsons, Govan, De la Cruz et al., 2011), which are important elements in the evaluation of patients with distress. In future studies, DHD should be evaluated by the semi-standardized approach using psychometric tools that allow comparisons between populations (Kremeike et al., 2018). This study is the beginning of a research area, but mainly, it may have a clinical application for the identification of the presence of DHD and the implementation of personalized treatments, and with it, contribute to decrease of the suffering of patients.

\section{Funding}

No funding was received for this project.

\section{Conflicts of interest}

Dr. Marvin Delgado-Guay receives partial support from the National Institutes of Health grant R01CA200867 and has not conflicts of interest. Oscar Rodríguez-Mayoral, Leticia Ascencio-Huertas, Emma Verástegui and Silvia Allende-Pérez receive partial support from Consejo Nacional de Ciencia y Tecnología (CONACyT) Sistema Nacional de Investigadores, and declare no potential conflict of interest.

\section{Acknowledgments}

We would like to thank Marina Paunero-Quezadas, MD., Laura Alicia Rios-Ochoa MD., and Adriana Peña-Nieves MPH., for their valuable collaboration in the development of this paper. Also, we would like to thank all the patients who participated in this study.

\section{REFERENCES}

Allende-Pérez, S. \& Verástegui-Avilés, E. (2013). La Medicina paliativa y el paciente con cáncer. Gaceta Mexicana de Oncología, 12(4), 211-212.

American Psychiatric Association. (2014). Manual diagnóstico y estadístico de los trastornos mentales - DSM 5. Quinta edición. Buenos Aires: Médica Panamericana. 
Armstrong, C. (2011). APA releases guideline on treatment of patients with major depressive disorder. American Family Physician, 83(10), 1219-1227.

Arrieta, Ó., Angulo, L. P., Núñez-Valencia, C., Dorantes-Gallareta, Y., Macedo, E. O., Martínez-López, D., ... \& Oñate-Ocaña, L. F. (2013). Association of depression and anxiety on quality of life, treatment adherence, and prognosis in patients with advanced non-small cell lung cancer. Annals of Surgical Oncology, 20(6), 1941-1948. doi: 10.1245/s10434-012-2793-5

Balaguer, A., Monforte-Royo, C., Porta-Sales, J., Alonso-Babarro, A., Altisent, R., Aradilla-Herrero, A., ... \& Voltz, R. (2016). An international consensus definition of the wish to hasten death and its related factors. PloS One, 11(1):e0146184. doi: 10.1371/journal.pone.0146184

Ballard, E. D., Pao, M., Henderson, D., Lee, L. M., Bostwick, J. M., \& Rosenstein, D. L. (2008). Suicide in the medical setting. Joint Commission Journal on Quality and Patient Safety, 34(8), 474-481.

Bellido-Pérez, M., Monforte-Royo, C., Tomás-Sábado, J., Porta-Sales, J., \& Balaguer, A. (2017). Assessment of the wish to hasten death in patients with advanced disease: A systematic review of measurement instruments. Palliative Medicine, 31(6), 510-525. doi: 10.1177/0269216316669867

Breitbart, W., Rosenfeld, B., Pessin, H., Kaim, M., Funesti-Esch, J., Galietta, M., ... \& Brescia, R. (2000). Depression, hopelessness, and desire for hastened death in terminally ill patients with cancer. JAMA, 284(22), 2907-2911. doi: 10.1001/ jama.284.22.2907

Bruera, E., Kuehn, N., Miller, M. J., Selmser, P., \& Macmillan, K. (1991). The Edmonton Symptom Assessment System (ESAS): a simple method for the assessment of palliative care patients. Journal of Palliative Care, 7(2), 6-9.

Chao, Y.-S., Boivin, A., Marcoux, I., Garnon, G., Mays, N., Lehoux, P., ... \& de Langavant, G. (2016). International changes in end-of-life practices over time: a systematic review. BMC Health Services Research, 16(1):539. doi: 10.1186/ s12913-016-1749-z

Chochinov, H. M., Wilson, K. G., Enns, M., Mowchun, N., Lander, S., Levitt, M., \& Clinch, J. J. (1995). Desire for death in the terminally ill. The American Journal of Psychiatry, 152(8), 1185-1191. doi: 10.1176/ajp.152.8.1185

Chochinov, H. M. (2016). Physician-Assisted death in Canada. JAMA, 315(3), 253254. doi: 10.1001/jama.2015.17435

Delgado-Guay, M. O., Hui, D., Parsons, H. A., Govan, K., De la Cruz, M., Thorney, S., \& Bruera, E. (2011). Spirituality, religiosity, and spiritual pain in advanced cancer patients. Journal of Pain and Symptom Management, 41(6), 986-994. doi: 10.1016/j.jpainsymman.2010.09.017

Houmann, L. J., Chochinov, H. M., Kristjanson, L. J., Petersen, M. A., \& Groenvold, M. (2014). A prospective evaluation of Dignity Therapy in advanced cancer patients admitted to palliative care. Palliative Medicine, 28(5), 448-458. doi: $10.1177 / 0269216313514883$

Julião, M., Barbosa, A., Oliveira, F., \& Nunes, B. (2013). Prevalence and factors associated with desire for death in patients with advanced disease: Results from a Portuguese cross-sectional study. Psychosomatics, 54(5), 451-457. doi: 10.1016/j.psym.2013.01.006

Kelly, B., Burnett, P., Pelusi, D., Badger, S., Varghese, F., \& Robertson, M. (2003). Factors associated with the wish to hasten death: A study of patients with terminal illness. Psychological Medicine, 33(1), 75-81. doi: 10.1017/ S0033291702006827

Kremeike, K., Galushko, M., Frerich, G., Romotzky, V., Hamacher, S., Rodin, G., ... \& Voltz, R. (2018). The DEsire to DIe in Palliative care: Optimization of Management (DEDIPOM) - a study protocol. BMC Palliative Care, 17(1):30. doi: 10.1186/s12904-018-0279-3

Kumar, V., Chaudhary, N., Soni, P., \& Jha, P. (2017). Suicide rates in cancer patients in the current era in united states. American Journal of Psychiatry - Residents, Journal, 12(1), 11-14. doi: 10.1176/appi.ajp-rj.2017.120104
Madeira, N., Albuquerque, E., Santos, T., Mendes, A., \& Roque, M. (2011). Death ideation in cancer patients: Contributing factors. Journal of Psychosocial Oncology, 29(6), 636-642. doi: 10.1080/07347332.2011.615381

Mehta, R. D. \& Roth, A. J. (2015). Psychiatric considerations in the oncology setting: Psychiatric considerations in the oncology setting. CA: A Cancer Journal for Clinicians, 65(4), 299-314. doi: 10.3322/caac.21285

Mercadante, S. \& Bruera, E. (2016). Opioid switching in cancer pain: From the beginning to nowadays. Critical Reviews in Oncology/Hematology, 99, 241248. doi: 10.1016/j.critrevonc.2015.12.011

Morita, T., Tsunoda, J., Inoue, S., \& Chihara, S. (1999). The Palliative Prognostic Index: A scoring system for survival prediction of terminally ill cancer patients. Supportive Care in Cancer: Official Journal of the Multinational Association of Supportive Care in Cancer, 7(3), 128-133.

Oken, M. M., Creech, R. H., Tormey, D. C., Horton, J., Davis, T. E., ... \& Carbone, P. P. (1982). Toxicity and response criteria of the Eastern Cooperative Oncology Group. American Journal of Clinical Oncology, 5(6), 649-656.

Polanski, J., Jankowska-Polanska, B., Rosinczuk, J., Chabowski, M., \& SzymanskaChabowska, A. (2016). Quality of life of patients with lung cancer. OncoTargets and Therapy, 9, 1023-1028. doi: 10.2147/OTT.S100685

Quill, T. E., Back, A. L., \& Block, S. D. (2016). Responding to patients requesting physician-assisted death: Physician involvement at the very end of life. JAMA, 315(3), 245-246. doi: 10.1001/jama.2015.16210

Rosenfeld, B., Breitbart, W., Galietta, M., Kaim, M., Funesti-Esch, J., Pessin, H., ... \& Brescia, R. (2000). The schedule of attitudes toward hastened death: Measuring desire for death in terminally ill cancer patients. Cancer, 88(12), 2868-2875. doi: 10.1002/1097-0142(20000615)88:12<2868::aid-cncr30>3.0.co;2-k

Saxena, S., Krug, E. G., Chestnov, O., \& World Health Organization (Eds.). (2014). Preventing suicide: A global imperative. Geneva: World Health Organization. https://apps.who.int/iris/bitstream/handle/10665/131056/9789241564779_eng. pdf? sequence $=1 \&$ isAllowed $=y$.

Strasser-Weippl, K., Chavarri-Guerra, Y., Villarreal-Garza, C., Bychkovsky, B. L., Debiasi, M., Liedke, P. E. R., ... \& Goss, P. E. (2015). Progress and remaining challenges for cancer control in Latin America and the Caribbean. The Lancet. Oncology, 16(14), 1405-1438. doi: 10.1016/S1470-2045(15)00218-1

Vehling, S., Kissane, D. W., Lo, C., Glaesmer, H., Hartung, T. J., Rodin, G., \& Mehnert, A. (2017). The association of demoralization with mental disorders and suicidal ideation in patients with cancer: Demoralization and Mental Disorders. Cancer, 123(17), 3394-3401. doi: 10.1002/cncr.30749

Wagner, F. A., González-Forteza, C., Sánchez-García, S., García-Peña, C., \& Gallo, J. J. (2012). Enfocando la depresión como problema de salud pública en México. Salud Mental, 35(1), 3-11.

Wilson, K. G., Chochinov, H. M., Skirko, M. G., Allard, P., Chary, S., Gagnon, P. R., ... \& Clinch, J. J. (2007). Depression and anxiety disorders in palliative cancer care. Journal of Pain and Symptom Management, 33(2), 118-129. doi: 10.1016/j.jpainsymman.2006.07.016

Wilson, K. G., Dalgleish, T. L., Chochinov, H. M., Chary, S., Gagnon, P. R., Macmillan, K., ... \& Fainsinger, R. L. (2016). Mental disorders and the desire for death in patients receiving palliative care for cancer. BMJ Supportive \& Palliative Care, 6(2), 170-177. doi: 10.1136/bmjspcare-2013-000604

Yates, J. W., Chalmer, B., \& McKegney, F. P. (1980). Evaluation of patients with advanced cancer using the Karnofsky performance status. Cancer, 45(8), 2220-2224. doi: 10.1002/1097-0142(19800415)45:8<2220::aidcncr2820450835>3.0.co;2-q

Zhong, B.-L., Li, S.-H., Lv, S.-Y., Tian, S.-L., Liu, Z.-D., Li, X.-B., ... \& Zhuo, C.-J. (2017). Suicidal ideation among Chinese cancer inpatients of general hospitals: prevalence and correlates. Oncotarget, 8(15), 25141-25150. doi: 10.18632/ oncotarget. 15350 